\title{
Pancreatitis associated protein as an early marker of acute pancreatitis
}

\author{
E Kemppainen, J Sand, P Puolakkainen, S Laine, J Hedström, V Sainio, R Haapiainen, \\ I Nordback
}

Second Department of Surgery, Helsinki University Central Hospital, Finland

E Kemppainen

P Puolakkainen

J Hedström

V Sainio

R Haapiainen

Department of Surgery, Tampere University Hospital and Tampere University, Finland J Sand

I Nordback

Department of Clinical Microbiology, Tampere University Hospital, Finland $S$ Laine

Correspondence to: Dr I Nordback Department of Surgery, Tampere University Hospital, Teiskontie 35 33520 Tampere, Finland. Accepted for publication 20 June 1996

\begin{abstract}
Background-Measuring serum pancreatitis associated protein (PAP) in acute pancreatitis has proved valuable in monitoring the course of the disease and the recovery of the patient.
\end{abstract}

Aims-The aim was to analyse the utility of PAP on admission as a diagnostic and prognostic marker of acute pancreatitis. Patients-Values of PAP were prospectively analysed in 80 healthy volunteers, 164 patients with abdominal pain but without pancreatitis, 109 patients with mild acute pancreatitis, and 38 patients with severe acute pancreatitis.

Methods-The diagnosis of acute pancreatitis was verified with clinical, laboratory, radiological, and in some cases findings at operation or necropsy.

Results-Mean (95\% confidence intervals) serum PAP values were 27 (24 to 29 ) $\mu \mathrm{g} / 1$ in healthy volunteers, 78 (59 to 96$) \mu g / 1$ in patients with abdominal pain, 191 (134 to 247) $\mu g / 1$, in patients with mild acute pancreatitis, and 599 (284 to 914) $\mu \mathrm{g} / \mathrm{l}$ in patients with severe acute pancreatitis. Differences between the groups were significant $(p=0 \cdot 04-0 \cdot 01)$. Despite the differences in means, the ranges overlapped between the groups. The sensitivity of PAP on admission to detect acute pancreatitis was $38 \%-53 \%$ and the respective specificity $89 \%-77 \%$ depending on the cut off level. The sensitivity of PAP to detect severe acute pancreatitis was $45 \%-68 \%$ and the specificity $74 \%-59 \%$ depending on the cut off level.

Conclusions-Admission PAP did not distinguish severe from mild acute pancreatitis better than $C$ reactive protein. Measurement of PAP does not give appreciable diagnostic advantages in the early phase of acute pancreatitis.

(Gut 1996; 39: 675-678)

Keywords: pancreatitis associated protein, acute pancreatitis, marker, early diagnosis.

Pancreatitis associated protein (PAP) is a recently discovered pancreatic exocrine secretory protein that is not detectable in pancreatic juice in normal conditions, but for which secretion is strongly induced in acute pancreatitis. ${ }^{1}$ The primary structure of PAP disclosed a significant similarity with reg/lithostatine, another pancreatic protein and has considerable homology with the carboxyl terminal region of $\mathrm{C}$ type lectins, ${ }^{2}$ which can explain its capacity to aggregate bacteria. ${ }^{3}$ It can be characterised as a pancreatic acute phase protein, probably not so important in the pathogenesis of acute pancreatitis, but representing endogenous defence mechanisms. ${ }^{4}$ Although PAP is secreted in zymogen granules from the acinar cells into the pancreatic juice, it also leaks from the pancreas into serum in acute pancreatitis. ${ }^{5}$ Raised serum concentrations of PAP have been detected after longterm alcohol consumption, and PAP has been considered as a probable marker of subclinical pancreatic injury. ${ }^{6}$

In a recent study, the monitoring of serum PAP in patients with acute pancreatitis provided a good method for the dynamic assessment of the severity of the disease and the recovery of the patient. ${ }^{5}$ Measurement of PAP also seems to provide a tool for differentiation of severe from mild pancreatitis early after admission, ${ }^{5}$ and this was considered of high value by the first interpreters of the results. ${ }^{7}$ However, there are no reports on the value of PAP in differentiating acute pancreatitis from other acute abdominal conditions. The aim of the present study was to analyse the utility of PAP on admission as a diagnostic and prognostic marker of acute pancreatitis.

\section{Methods}

The study was prospectively conducted from October 1992 to January 1995 in the University Central Hospitals of Tampere and Helsinki in Finland. It was designed in three steps: (1) to establish the reference value of PAP in healthy subjects, (2) to establish the reference value in populations having abdominal pain from causes other than pancreatitis, and (3) to analyse the clinical utility of serum PAP in the early diagnosis of acute pancreatitis of different aetiologies.

For step 1 serum samples were collected from 80 healthy adult volunteers (Table I), and stored at $-70^{\circ} \mathrm{C}$ for later assays of $\mathrm{PAP}, \mathrm{C}$ reactive protein, and serum amylase to create a local reference material for the study.

For step 2, serum samples were collected from 164 patients admitted to the emergency departments of Tampere and Helsinki University Central Hospitals with various acute abdominal problems (Tables I and II). Pancreatitis was excluded in these patients on clinical, laboratory, radiological, and in 13 cases, findings at endoscopy or operation.

For step 3, serum samples were collected from 147 patients with acute pancreatitis on 
TABLE I Clinical data of patients in the study groups

\begin{tabular}{lllll}
\hline & $\begin{array}{l}\text { Healthy } \\
\text { volunteers }\end{array}$ & $\begin{array}{l}\text { Control group with } \\
\text { abdominal pain }\end{array}$ & $\begin{array}{l}\text { Mild acute } \\
\text { pancreatitis }\end{array}$ & $\begin{array}{l}\text { Severe acute } \\
\text { pancreatitis }\end{array}$ \\
\hline Patients (n) & 80 & 164 & 109 & 38 \\
Female/male & $46 / 34$ & $74 / 90$ & $18 / 91$ & $9 / 29$ \\
Age (y) (mean (range)) & $29(19-59)$ & $52(11-92)$ & $49(18-87)$ & $42(21-61)$ \\
Duration of symptoms (mean (days)) & & & $1 \cdot 4$ & $1 \cdot 1$ \\
Relapsing pancreatitis (\%) & & & 37 & 19 \\
\hline
\end{tabular}

TABLE II Patients with acute abdominal disorders of extrapancreatic origin

\begin{tabular}{|c|c|c|c|}
\hline Diagnosis & $\begin{array}{l}\text { Patients } \\
\text { (n) }\end{array}$ & Diagnosis & $\begin{array}{l}\text { Patients } \\
\text { (n) }\end{array}$ \\
\hline Acue appendicitis & 29 & Ulcerative colitis & 1 \\
\hline Gall bladder stones* & 17 & Abdominal blunt trauma ${ }^{\star}$ & 1 \\
\hline Intestinal obstruction & 17 & Paralytic ileus ${ }^{\star}$ & 1 \\
\hline Gastrointestinal bleeding & 15 & Urinary retention & 1 \\
\hline Acute gastroenteritis and gastritis & 15 & Sigmoid perforation & 1 \\
\hline Acute sigmoid diverticulitis & 11 & Hepatic cirrhosis & 1 \\
\hline Ureterolithiasis & 8 & Acute cholecystitis ${ }^{\star}$ & 1 \\
\hline Duodenal or gastric ulcer ${ }^{\star}$ & 6 & Gall bladder tumour (cancer) & 1 \\
\hline Cholangitis` & 5 & Prostate tumour (cancer) & 1 \\
\hline Urinary infection & 5 & Ventral hernia & 1 \\
\hline Ovarian tumour (cancer) & 2 & Caecal tumour (cancer) & 1 \\
\hline Abdominal arterial angina ${ }^{\star}$ & 2 & Gastric retention ${ }^{\star}$ & 1 \\
\hline Aneurysm of abdominal aorta ${ }^{\star}$ & 1 & Cause unknown & \\
\hline Oesophagitis & 1 & (acute pancreatitis excluded) & 19 \\
\hline
\end{tabular}

^Acute pancreatic damage has been reported to coincide sometimes with these conditions, but was not diagnosed in the present cases.

admission to hospital, during the diagnostic procedures of the emergency departments of the two participating hospitals.

The diagnosis of acute pancreatitis was based on a history of prolonged upper abdominal pain with one or more of the following clinical features: vomiting, fever, tachycardia, abdominal tenderness, rebound, distension, bowel paralysis, Grey Turner's sign, or Cullen's sign. Increased amylase activity was considered to suggest acute pancreatitis, but was not used on its own as a diagnostic criterion. Amylase thresholds were over 900 IU/l (normal range $<300 \mathrm{IU} / \mathrm{l}$ ) in serum and over $6000 \mathrm{IU} / 1$ (normal range $<2000 \mathrm{IU} / \mathrm{l}$ ) in urine. The diagnostic of acute pancreatitis was confirmed with contrast enhanced computed tomography in 69 patients, and in some cases with findings at operation or necropsy.

\section{PATIENTS}

The acute pancreatitis group of 147 patients (Table I), consisted of 109 having mild acute pancreatitis and 38 having a severe form of the disease. Severity of the pancreatitis was assessed by the clinically based classification system of the Atlanta Symposium. ${ }^{8}$ In that system severe acute pancreatitis is characterised by the following features: three or more

TABLE III Mean (95\% CI) serum PAP concentration, serum amylase activity, and serum $C$ reactive protein concentration on admission

\begin{tabular}{lccc}
\hline & $P A P(\mu g /)$ & Amylase (IU/) & $C R P(m g /)$ \\
\hline Healthy subjects & $27(24 \text { to } 29)^{\star}$ & $200(186$ to 215$)$ & $5(5$ to 6$)$ \\
Abdominal pain reference group & $78(59 \text { to } 96)^{\star}$ & $189(175$ to 202$)$ & $39(31$ to 48$)$ \\
Mild pancreatitis & $191(134 \text { to } 247)^{\star}$ & $2114(1657$ to 2572$)$ & $41(30$ to 53$)$ \\
Severe pancreatitis & $599(284 \text { to } 914)^{\star}$ & $1581(970$ to 2191$)$ & $146(98$ to 195$)$ \\
All cases of pancreatitis & $296(202 \text { to } 390)^{\star}$ & $1997(1617$ to 2377$)$ & $70(52$ to 86$)$
\end{tabular}

$\star$ Differences are significant between all groups in PAP (Mann-Whitney $U$ test).

Amylase differences are significant between controls and patients with pancreatitis.

The differences in $\mathrm{C}$ reactive protein are significant between controls and patients with

pancreatitis and between patients with mild and severe pancreatitis.
Ranson criteria, eight or more APACHE II; organ failure defined as shock, pulmonary insufficiency, renal failure or gastrointestinal bleeding; systemic complications, such as disseminated intravascular coagulation or severe metabolic disturbances; and local complications, such as necrosis, abscess, or pseudocyst.

The aetiology of acute pancreatitis was alcohol misuse in $103(70 \%)$ patients, based on recent alcoholism and exclusion of other causes. Twenty two $(15 \%)$ patients had gall stone pancreatitis based on verification of gall stone disease by ultrasonography, endoscopic retrograde cholangiopancreaticography (ERCP), operation, or necropsy. Five patients $(4 \%)$ had post-ERCP pancreatitis, four (3\%) hypertriglyseridaemia pancreatitis, and $13(9 \%)$ a pancreatitis of unidentified aetiology.

ASSAY PROCEDURES

Serum amylase activity was measured with an enzymatic colorimetric test, using 2-chloro4-nitrophenyl-B-D-malto-heptaoside ( $4 \mathrm{mmol} / \mathrm{l}$ ) as a substrate. The absorbance of the coloured products was measured at $405 / 660 \mathrm{~nm}$ with a Hitachi 717 autoanalyser. Serum amylase $<300$ $\mathrm{U} / \mathrm{l}$ and urine amylase $<2000 \mathrm{U} / \mathrm{l}$ were considered normal. $\mathrm{C}$ reactive protein was determined using an immunoturbidometric method with antiserum and standards from Orion Diagnostica, Finland. The upper reference limit was $10 \mathrm{mg} /$.

Concentration of PAP was measured with a new commercial kit (PANCREPAP) for assaying human PAP (Dynabio, La Gaude, France). Its principle is based on a sandwich immunoenzymatic system, in which the samples are bound by specific antibodies. Bound PAP is then recognised by polyclonal anti-PAP antibodies coupled to biotin. After washing, antigen-antibody complexes are detected by an avidin-peroxidase complex and are visualised by the addition of a chromogenic substrate. The intensity of the colour reaction is proportional to the quantity of the PAP bound in the first step and can be measured spectrophotometrically.

\section{STATISTICAL ANALYSIS}

Values in each group are given as mean and $95 \%$ confidence intervals (95\% CIs). A two tailed Mann-Whitney $U$ test was used to calculate the significance of differences between the groups. Differences of $p<0.05$ were considered significant.

\section{Results}

In the 80 healthy volunteers serum PAP concentrations remained low and the idividual variation was usually small (Table III), but few showed high or low PAP concentrations (range $0 \cdot 1-63 \mu \mathrm{g} / 1)$. Serum C reactive protein concentrations and amylase activity remained within the reference range (Table III).

In the 164 patients with acute abdominal pain but without pancreatitis, serum PAP was 
higher than in the healthy volunteers (Table III). The range of the observations was 4-991 $\mu \mathrm{g} / \mathrm{l}$. Concentration of PAP was a little higher in the 43 patients (Table II) with the reported association with pancreatic damage (in the present cases pancreatitis could not be diagnosed) than in the remaining 121 patients (75 (50-101) $\mu \mathrm{g} / \mathrm{l} v 89(56-124) \mu \mathrm{g} / \mathrm{l}, \mathrm{p}<0.53)$. In all the 164 patients $C$ reactive protein concentration but not the amylase activity was higher than in the healthy volunteers (Table III).

In the 147 patients with pancreatitis the PAP on admission was significantly greater than that of healthy volunteers and patients with acute abdominal pain without pancreatitis (Table III). Concentrations of PAP were significantly more increased in severe pancreatitis than in mild pancreatitis (Table III). The range of admission PAP values was wide (15-4076 $\mu \mathrm{g} / \mathrm{l})$. Admission PAP did not differ significantly between the patients with various pancreatitis aetiologies, or between the patients with the first and recurrent acute pancreatitis (data not shown). Also $\mathrm{C}$ reactive protein and amylase were increased in the patients with pancreatitis compared with healthy volunteers. Furthermore, $\mathrm{C}$ reactive protein differed between patients with mild and severe pancreatitis (Table III).

Table IV presents the sensitivities and specificities at various cut off values of admission PAP and $\mathrm{C}$ reactive protein to identify pancreatitis in patients with acute abdominal pain, and the severity of pancreatitis in patients with acute pancreatitis or in patients with acute abdominal pain. In the patients with pancreatitis the mean lapse between the onset of symptoms and the admission to hospital was 31 hours. When studied separately, the 66 patients who were admitted within 24 hours after the onset of symptoms and the 81 patients who were admitted later did not differ in respect to detection of pancreatitis by PAP (sensitivities $45 \%$ v 50\%, specificities $85 \% v$ $89 \%)$.

\section{Discussion}

Previously the early biochemical diagnosis of pancreatitis and the assessment of the severity of the disease were based either on the measurement of released active digestive enzymes in circulation (as specific to the pan-

TABLE IV Sensitivities (Sens) and specificities (Spec) of admission PAP and CRP to identify pancreatitis in patients with acute abdominal pain, and the severity of pancreatitis in patients with acute pancreatitis or in patients with acute abdominal pain

\begin{tabular}{|c|c|c|c|c|c|c|}
\hline & \multicolumn{3}{|c|}{$P A P(\mu g /)$} & \multicolumn{3}{|c|}{$C R P(m g /)$} \\
\hline & Cut off & Sens & Spec & Cut off & Sens & Spec \\
\hline $\begin{array}{l}\text { Acute pancreatitis in acute } \\
\text { abdominal pain }\end{array}$ & $\begin{array}{r}80 \\
100 \\
120 \\
140\end{array}$ & $\begin{array}{l}53 \\
48 \\
42 \\
38\end{array}$ & $\begin{array}{l}77 \\
82 \\
87 \\
89\end{array}$ & $\begin{array}{r}40 \\
50 \\
70 \\
100\end{array}$ & $\begin{array}{l}55 \\
39 \\
33 \\
20\end{array}$ & $\begin{array}{l}68 \\
75 \\
78 \\
87\end{array}$ \\
\hline $\begin{array}{l}\text { Severe pancreatitis in acute } \\
\text { pancreatitis }\end{array}$ & $\begin{array}{l}100 \\
120 \\
140 \\
180\end{array}$ & $\begin{array}{l}68 \\
68 \\
66 \\
45\end{array}$ & $\begin{array}{l}59 \\
65 \\
71 \\
74\end{array}$ & $\begin{array}{r}80 \\
100 \\
120 \\
140\end{array}$ & $\begin{array}{l}70 \\
60 \\
57 \\
57\end{array}$ & $\begin{array}{l}84 \\
92 \\
93 \\
96\end{array}$ \\
\hline $\begin{array}{l}\text { Severe pancreatitis in acute } \\
\text { abdominal pain }\end{array}$ & $\begin{array}{r}80 \\
120 \\
140 \\
180\end{array}$ & $\begin{array}{l}73 \\
71 \\
68 \\
63\end{array}$ & $\begin{array}{l}78 \\
82 \\
87 \\
89\end{array}$ & $\begin{array}{r}50 \\
80 \\
100 \\
120\end{array}$ & $\begin{array}{l}71 \\
68 \\
61 \\
58\end{array}$ & $\begin{array}{l}75 \\
83 \\
87 \\
89\end{array}$ \\
\hline
\end{tabular}

creas as possible), their precursors, or inactive residues released during the activation of the enzymes, or on the measurement of the body inflammation parameters. ${ }^{9-11}$ Amylase activity and $\mathrm{C}$ reactive protein concentration have gained wide popularity in clinical practice, largely due to the easy, rapid, and automated methods of measurement. However, these methods are far from perfect in detecting pancreatitis. Neither is specific to pancreatitis. Furthermore, in a patient with pancreatitis amylase activity is of no value in identifying patients with severe pancreatitis. ${ }^{12} \mathrm{C}$ reactive protein often increases more after the admission, making the admission identification of severe pancreatitis sometimes difficult. ${ }^{13}$ Because PAP is neither a digestive enzyme nor a marker of general body inflammation, ${ }^{14}$ it is induced in the pancreas in acute pancreatitis when pancreatic enzyme synthesis is reduced, ${ }^{5}$ it is thought to be a pancreatic acute phase protein, ${ }^{4}$ and it has been shown to be valuable in monitoring the patients with acute pancreatitis, ${ }^{5}$ we studied the value of PAP in the early diagnosis of pancreatitis and the severity of the disease.

The present study showed that the admission PAP was significantly increased in patients with acute pancreatitis compared with healthy volunteers and patients with other causes of acute abdomen. However, although the $95 \%$ CIs did not overlap between the study groups, the ranges did. Such overlap resulted in unacceptably low sensitivities and specificities, independent on the cut off level used. Thus, serum PAP measurement on admission to hospital cannot be recommended for the diagnosis of acute pancreatitis.

A low sensitivity of PAP in diagnosing acute pancreatitis was not unexpected; PAP is a protein, of which detection in high concentration in serum requires preceding cellular induction, synthesis, and a leak into the circulation. A previous study showed a three to four day lapse before PAP concentrations increased to hundreds of units $(\mu \mathrm{g} / \mathrm{l})$ in a patient with severe pancreatitis. ${ }^{5}$ The unsatisfactory specificity was more unexpected. Very recently, however, a protein immunoreactively similar to PAP has been found in jejunum and ileum, in Paneth cells, and in a few globlet cells. $^{2}$ This may explain why some patients with other causes of acute abdomen also had concentrations of serum PAP greater than the healthy volunteers.

The present study showed that the admission PAP was significantly greater in the patients with severe than in those with mild pancreatitis. When compared with $\mathrm{C}$ reactive protein, however, the sensitivities and specificities of PAP were slightly lower. Thus measurement of C reactive protein gives better prognostic information than PAP. The sensitivities and specificities of PAP on admission to distinguish the patients with severe pancreatitis from patients with other causes of acute abdomen were slightly higher than those of $\mathrm{C}$ reactive protein. This, however, may be due to the nature of $\mathrm{C}$ reactive protein being a non-specific marker of body inflammatory response. 
In a severely ill patient with acute abdomen, severe acute pancreatitis is one option in the differential diagnosis. $C$ reactive protein may still be low and amylase activity of a few hundred units does not support or exclude pancreatitis. Then PAP measurement would give important information. However, the sensitivity and specificity of PAP to detect severe pancreatitis was not better than that published from contrast enhanced computed tomography. ${ }^{15-18}$

In conclusion, serum PAP meaurement on admission to hospital was not found to have satisfactory reliability in the diagnostic evaluation of acute pancreatitis.

This work was supported by grant from the Paulo Foundation, Finland (IN). We thank Dr J-C Dagorn, U 315, INSERM, Finland (IN). We thank Dr J-C Dagorn, U
Marseille, France, for providing the PAP kits.

1 Keim V, IovannaJL, Orelle B, VerdierJ-M, Büsing M, Hopt U, et al. A novel exocrine protein associated with pancreatic transplantat

2 Masciotra L, Lechene De La Porte P, Frigerio J-M, Dusetti NJ, Dagorn J-M, Iovanna JL. Immunohistochemical localisation of pancreatitis associated protein in human small intestine. Dig Dis Sci 1995; 40: 519-24.

3 Iovanna JL, Frigerio J-M, Dusetti NJ, Ramare F, Raibaud P. Lithostatine, an inhibitor of $\mathrm{CaCO}_{3}$ crystal growth in pancreatic juice, induces bacterial aggregation. Pancreas 1993; 8: 597-601.

4 Iovanna JL, Orelle B, Keim V, Dagorn J. Messenger RNA sequence and expression of rat pancreatitis associated protein, a lectin-related protein overexpressed during acute experimental pancreatitis. I Biol Chem 1991; 266: 24664-9.

5 Iovanna JL, Keim V, Nordback I, Montalto G, Gamarena J Letoublon C, et al. Serum levels of pancreatitis-associated protein as indicators of the course of acute pancreatitis. Gastroenterology 1994; 106: 728-34.

6 Nordback J, Jaakkola M, Iovanna JL, Dagorn J-M Increased serum pancreatitis associated protein (PAP) concentration after longterm alcohol consumption further evidence for regular subclinical pancreatic damage after heavy drinking? Gut 1995; 36: 117-20.

7 Grendell J. Acute pancreatitis. Current Opinion in Gastroenterology 1995; 11: 402-6.

8 Bradley E. A clinically based classification system for acute pancreatitis. Summary of the international symposium on acute pancreatitis, Atlanta, Ga, September 11 through 13 1992. Arch Surg 1993; 128: 586-90.

9 Clavien PA, Burgan S, Moossa AR. Serum enzymes and other laboratory tests in acute pancreatitis. Br $f$ Surg other laboratory test

10 Gumaste VV. Diagnostic tests for acute pancreatitis. Gastroenterologist 1994; 2: 119-30.

11 Schölmerich J, Henisch A, Leser H-G. Diagnostic approach to acute pancreatitis: diagnosis, assessment of etiology and prognosis. Hepatogastroenterology 1993; 40: 531-7.

12 Nordback I. Value of monitoring amylase activities in patients with pancreatitis. Lancet 1985 ; ii: 1092 .

13 Puolakkainen P, Valtonen V, Paananen A, Schröder T. C-reactive protein (CRP) and serum phospholipase $A_{2}$ in the assessment of severity of acute pancreatitis. Gut 1987 ; 28: 764-71.

14 Keim V, Iovanna J, Rohr G, Usadel K, Dagorn JC. Characterisation of rat pancreatic secretory protein associated with pancreatitis. Gastroenterology 1991; 100: 775-82.

15 Moulton JS. The radiologic assessment of acute pancreatitis and its complications. Pancreas 1991; 6: 13-22.

16 Balthazar EJ, Robinson DL, Megibow AJ, Ranson JH Acute pancreatitis: value of CT in establishing prognosis Radiology 1990; 174: 331-6.

17 Banks PA. Predictors of severity in acute pancreatitis. Pancreas 1991; 6: 7-12.

18 Kivisaari L, Schröder T, Sainio V, Somer $K$, Strandenskjöld-Nordenstam CG. CT evaluation of acute pancreatitis: 8 years clinical experience and experimental evidence. Acta Radiol Suppl 1991; 20: 20-4. 